\title{
Primary hyperoxaluria type 3
}

INSERM

\section{Source}

INSERM. (1999). Orphanet: an online rare disease and orphan drug data base. Primary hyperoxaluria type 3. ORPHA:93600

Primary hyperoxaluria type $3(\mathrm{PH} 3)$ is a disorder of glyoxylate metabolism that can be asymptomatic or characterized by oxalate nephrolithiasis. 